\title{
Legal Status of Embryo Transfer
}

\author{
Hiva Mohammad AliPour \\ Master of Degree Course Student of Private Law, Department of Law, Bandar e Anzali International Branch \\ Islamic Azad University, Bandar e Anzali, Iran. \\ Mohammadreza Sharafatpeima
}

PhD, Assistant Professor, Department of Private Law, Bandar Anzali Branch, Islamic Azad University

Bandar Anzali, Iran. Corresponding Author

\section{Doi:10.5901/mjss.2015.v6n6s6p80}

\begin{abstract}
Transmission of embryo is done when the ovum is removed and prolific in embryo and traversed its complete evolution steps. This step is performed in second, third or fifth day after removing ovum. Depend on situation, between one to three embryos are selected and transfer into mother's womb. The aim of present research is to discuss legal status of embryo transmission and what is legal situation of it? Based on data collected from legal points, problem of infertile family has been facilitated somewhat. Thus, there is not prohibition in this regard in Iran's law. Also, the strategies are taken in order to protect child. If it is cited that couples duties and tasks of receivers and the child are like as son from maintenance and education and respect. But from casual effects due to embryo transmission in our law, there is not explicit law. So that it is not pointed to prohibition of matrimony between child and couples and it is not about alimony that the couples are entitled or not. In addition to, about heritage, civil law did not accept heritage between child and receivers, because based on traditional theory, the child belongs to sperm owner and heir from them.
\end{abstract}

Keywords: Embryo, Artificial Zygosis, Embryo Transmission, Civil Law.

\section{Introduction}

As for extension of human knowledge and emergence new approaches in domain of experimental; sciences, there are legal complicated problems and subjects and they need suitable solutions. Embryo transmission is possible with different methods. Zygosis out of womb or reproduction out of womb without intercourse and reproduction of human womb by intercourse are from unwanted problems which have been changed during time. Since past times, mass media considered scientific researches and results due to horizons pertinent to new methods about treat infertile. In beyond probable developments and recognize new methods for reproduction, the questions are asked so that why ethical and legal aspects of this question is not considered and why the regulations and instructions are imperfect and cannot be respond to more questions of the couples who use new infertile methods? Thus the experts shall be respondent to questions by ethical and legal discussion. (Feizolllahi, 2010, p. 13) unfortunately, the laws and researches are not similar. For example, we confront with long-term delays about embryo and its problems, sometime; there are sociology fields which the policy maker cannot neglect it. John Bernard has known sentence and says: what is not science, it is not ethical. Without neglecting what is ethical, necessarily it is not science and the ethics is not but science. As for the above, the couples who used new treatment methods shall know the laws. Thus the consulting with the experts will be effective on treatment process and future of their children. As for above, the researcher is following to respond question, is there difference between views of Juris consults about embryo transmission from ovum or sperm?

\section{Theoretical Framework}

\subsection{History of Embryo Transmission}

Embryo transmission as scientific method is new phenomena relatively and derived from current knowledge. The first experiment was done by one of the Embryoany scientists named Ludwig Jacubi ${ }^{1}$ at 1765 on fishes. Then in Italia and Russia, artificial zygosis was done upon animals and publicized on humans. At 1799 in England and at 1866 in United 
States, scientists and at 1868 in women hospital of New York City of French did their experiments. Ten years later, one of French scientists reported that from 72 women who have given artificial zygosis, 41 cases had positive results. Since years, this subject has been considered by the scientists. (Safaee, 2001, p. 99)

At 1914, one of English doctors who was reside at Egypt named Dr. Jamison², there is method for pregnancy of women between primitives so that caused the women are pregnant and when they die. This happening caused the English doctor thought and found that the primitive women incantation to part of animals wool like goat and gave it to infertile women to rub on her womb and believed that this method causes woman pregnant or die. (Mirhashemi, 2004, p. 2)

In Islamic verdicts, artificial zygosis had not background as know from scientific and practical point of view. Thus, artificial zygosis could not fine in Islamic texts and narrations and traditions to certify or reject it, but about pregnancy of woman by another woman by lesbianism which causes pregnancy, this action is prohibited and the verdicts are about it. (Hazrati, 2003, p. 78)

In Iran after ending imposed war, the researches were done about fertility out of womb and artificial zygosis. At December 11, 1990, the first child from artificial zygosis was born in Afahar Hospital of Shahid Sadoghi University, but the basic problem in countries like Iran, is religious thoughts and legal terms and special regulations which prohibit applying some of new methods of fertility. (Jafarzadeh, 2000, p. 53)

\subsection{Define Concepts and Idioms}

\subsubsection{Embryo}

Embryo is derived from Jonan. In Arabian language, it is defined (Arabian Lnaguage, volume 13, p. 92), thus embryo means covered and hidden thing and is regarded as when the child is on mother bell. (Amid, 1995, p. 473)

Dictionary of Dr. Moin interpreted embryo as: embryo, thing that is obtained after zygosis by spermatozoid and after pristine divisions of cells, but its growth period is on mother's womb. (Moin, 2008, p. 394)

\subsubsection{Embryo Transmission}

Embryo transmission consists of transmission, embryo, transmission means replacing. It seems that embryo transmission is not correct because replacing is emergency and inactive verb, which means embryo, is transferred. The verdicts are discussed are not due to permission on transmission. It is not said embryo transmission is permissible or not but it said replacing of embryo is permissible or not from an in vitro to woman's womb, then it is suitable instead of embryo transmission. (Sum of articles, 2010, p. 263)

\subsubsection{Artificial Zygosis}

Artificial zygosis is to insert man's sperm into woman's womb by medical tools or another tool instead of intercourse. Zygosis means pregnancy and to be pregnant. As displayed above, zygosis is not far from its lexical mean, it means pregnancy of woman by man's spermatozoide by medical tools and artificial equipment without intercourse. (Nayebzadeh, 2001, p. 9)

\subsection{Types of Methods for Embryo Transmission}

The most important methods used for fertility are based on three:

\subsubsection{Sperm Injection Method, IUI ${ }^{3}$}

The method of IUI is that sperm is provided by different methods who is husband and after washing and separation, alive sperms ate entered into womb by special medical needles. As for possibility of sperm from stranger and non-spouse, IUI method is done as following: injection with husband sperm and use of sperm of non-spouse.

\subsubsection{Injection with Use of Husband Sperm}

In this method, the sperm required is provided with woman laying simultaneously. In Iranian remedial centers, at morning, 
when woman reached to her best time for womb, sperm is provided from her husband and washed for 1 or 2 hours and entered into woman womb. (Feizollahi, 2010, p. 31)

Use of these methods is done when infertility is not recognized and some of disorders of sperm, unsuitable mucus in edge of womb and weakness of sperm. Since the sperm shall be washed and then enter into woman womb, they shall be provided by legal methods and enter into womb. This method is used more than 4 for each couple and chance of pregnancy is $35 \%$ after 4 periods. (Same)

\subsubsection{Use of Sperm of Non- Spouse}

When husband of woman is exposed Azo Spermic disease (lacking sperm) or there is possibility of genetically disease, sperm is obtained from other man in order to pregnancy. The method for providing and entering is same as previous method. About frozen sperm from fresh sperm after and before washing, the basic problem is permission or prohibition of this action based on theory of jurists which is considered. (Same, p. 32)

1 - Intra Uterine Insemination

\subsubsection{MF Embryo Transmission}

The most prevalent method for pregnancy is by helping methods like reproduction. After preparation of sexual cells of woman and man, they locate each other in in vitro to perform zygosis, after zygosis of sperm and ovum, embryo is formed and grows. In reproduction of cellular step and from date 0

zygosis, 4-8 embryos enter into womb to continue their growth. (Lawrence Hill, 1966, p354)

In cases of infertility because of inability of sperm in order to reach in womb or problems in zygosis, this method is used. (Nayebzaeh, 2001, p. 27), of course, it is possible the fertile cells are not transferred into womb but they froze and maintain for future uses.

IVF method is obtained and results to pregnancy.

Ovum preparation: in order to provide ovum by stimulated drugs of ovum, ovary is stimulated and many ovum are produced. Time of mature ovum is recognized by sonography and estimate serum stradiul which is started from $8^{\text {th }}$ day of treatment (Ghafari, 2003, p. 10)

Preparation of Sperm: the sperm is provided in morning of collecting ovum by legal method and prepare after washing and separated fresh and active materials.

4 - In Vitro Fertilization

Sperm and ovum zygosis and forming zygote in Lab.: after preparation of sperm and ovum as explained in previous paragraphs, prepared sperms located their proximity to provide suitable cultivation environment at 37 degree during night. (Same, 75, 76, 81)

Transmission of Embryo into Womb: usually, the embryos are more than three in In vitro but in order to prevent pregnancy of multi twins, two or three embryos enter into woman womb by needle and the remaining are maintained after frozen with using embryo saving method in embryo source and about unsuccessful pregnancy, use in other treatment. About pregnancy, the patient who is owner of embryo and present it to others. (Ghafari, 2003, p. 12)

Prescription of Progesterone Hormone: in order to prepare womb for maintain and locating embryo, progesterone hormone is prescribed and this hormone is performed after 12 days. Hormone prescription is continued in order to maintain it and disconnect it. (Same, p.12)

\subsection{Micro Injection Method, ICSI5}

ICSI method is other fertility methods and is most expensive to IVF and shall be performed by doctor. Since ovum has Gylco coverage (sugar and protein) Zona Pellucida, and contain cytoplast membrane which prevent from sperm into movement and shape and disconnect zygosis and fertility. Thus, when infertility is due to inability of sperm of man, after preparation of woman sexual cells by legal method, sperm injects into womb by medical tools and after zygosis, and locate it after 48 hours from growth and 73 hours after zygosis, this method is named as sperm injection. (Akhundi, 2002, p. 31)

1 -Intra cytoplasmic sperm Injection

1 -Zona Pellucida.

In first information published in world, increments of danger of maternal disorders are not seen in persons. Since it is not what scale of danger for children. And will be exposed to infertility of not? But the fact is micro injection method is 
great revolution in treatment of infertility and caused fertility progress by using sperms naturally. (Jequier AM.Malelnferility 2000, p. 357)

\subsubsection{Legal Points of Embryo Transmission}

The lawyers like Naser Katouziyan, Asadollah Emami, and Seyedhossein Safaee discussed it from sociology pint of view without couple relation and some objected it.

Embryo transmission and artificial zygosis disturb family calmness and marital life exposes wife and husband against mental conflictions and the husband cannot tolerate child who is other fetus and interest him, especially the child lacks specifications. (Hazrati, 2008, p. 256)

Embryo transmission and artificial zygosis are non-cleanable odium and is like as adultery. This action descends man because the animals have not certain laws in searching male gender. Embryo transmission causes the persons intercourse with their relatives unknowingly and this is harmful from scientific and ethical point of view, because it is possible the child born marries with his relatives and this is so inadvisable. (Safaee, 1997, p. 100)

Thus, in the case of permission, sperm or ovum is from stranger of non-spouse which is scorn and it is possible child exposes mental security and if he/she is unknown relative, deprive his right as well as lacking mental security. (Rezayatnia, 2003, p. 113)

One of the God's wisdoms is continuation and survival of family about birth and pregnancy, in one side, if permission verdict is from stranger man to stranger woman; it's necessary is to permission of zygosis of father fetus to girl and son to mother and sister, because there is not difference between intimate and illegal and maybe sperm of pagan is injected into Muslim which is opposite to Islamic genetics effects. (Same)

\subsubsection{Legal Status of Child born due to Artificial Zygosis or Husband Sperm}

About legitimacy or illegitimacy of child and its effects, there is not explicit verdict. It is possible to suppose that relative of child is legitimate when he born from intercourse between man and woman and based on articles 1158 and 1159 of civil law, the intercourse is recognition criteria, but this legal point of view is imperfect, because intercourse is concluding fetus and from separation point of view, it is considered by the policy makers and otherwise, there is not property about intercourse to accept that the intercourse plays role in relative of child, because if intercourse has effect, relative legitimate caused like rubbing calf to calf and stimulating and penetration of husband sperm into woman womb or other bodily touches are problematic and no jurists doubt it and the jurisconsults don't doubt it. (Almomemn, 1415, p. 80)

\subsubsection{Legal Status of Child born due to Artificial; Zygosis or Stanger Sperm}

Regardless permission or aspect of artificial zygosis with stranger sperm, we want to discuss what relation between child with mother and father is:

1. Relation of child and mother: what is relation between a women is fertile by injection of stranger sperm, and fetus nurtured in her womb and child who is born? Is relative of woman to artificial zygosis is unknown, the child is doubt one and belong to mother and if woman knows artificial zygosis, the child is due to adultery and doesn't belong to mother. (Shahidi, 2006, p. 366)

2. Relation of child with owner of fetus: in legal relation with owner of fetus, there are different theories with owner, some believed that if owner of sperm is unaware zygosis, the child is same as doubt one and if the owner of sperm is aware, the child is like as adultery and say: when child belongs to father, who is born by customary method, and if the child is by non-customary method like artificial zygosis, he doesn't belong to owner of sperm and this phenomena damages family like adultery. (Rouhani Aliabadi, 2007, p. 288) other believed that child due to artificial zygosis including owner is aware it to unaware it, is owner of child from biologically and legal point of view because fetus is hidden. (Rouhani, 2010, p. 10)

3. Relation of child with husband: if married woman possess child with artificial zygosis, discussion is, what is relation between two?

In Iran legal discussions, there is not verdict about it and from fact and nature point of view; there is not method for knowing who legal owner of child is and from legal matrimony, if the child is girl, it is permissible to marry but from practical point of view, each child is born from married woman, will be belonged to her husband. (Alvaledfarash) 


\section{Permission of Embryo Transferred from Legal Point of View}

About permission or lacking permission of embryo transmission into womb of other woman, there is not explicit law in civil law of Iran, but since if the case is being prohibited by law, since all human actions and behaviors are permissible if they don't conflict with public discipline. About our subject, embryo transmission into stranger womb causes strength of family and can remove problems of families are not able to give child. (Ahari, 2003, p. 126)

\subsection{Legal Effects of Embryo Transmission}

\subsubsection{Maintenance}

Article 1168 of civil law says: the parents shall maintain the child. Thus, whoever has child shall maintain him; the maintenance will be undertaken by father and mother since law considers rights of child.

The question is; who is responsible for maintenance of child during milk feeding in presenting embryo? It seems as for expedient of child, his maintenance is being given to the owner, whereas, as said in narrations, they resolved problem and one of childish verdicts is maintenance. Maybe, the most difficult problem is about it. (Khoei, 1421, p. 320)

\subsubsection{Maintenance and Volition theory}

Acceptance of volition theory is solvable and has not barriers and as for protests of owners of sperm, the receivers can maintain child. This problem is solvable to relative of mother as for attribution of mother to owner of sperm, in this case volition of child is observed. Article 3 of law for presenting embryo accepted it.

\subsubsection{Relative}

Importance of relative discussion is so vast. Because, by recognition child due to it, other problems like intimacy, alimony, maintenance and supervision are solved. By discussion jurists theory, we can conclude that they voted to mother of child and in this case, by recourse to consent verdicts, it is voted to child of owner of sperm. But in Iran's law, it is not accepted complete annex. Article 3 of law for presenting embryo said: duties and tasks of couples are like as duties of parents. Intimacy is exceptional verdict and is not publicized about doubt. (Safeee, 2002, p. 69)

\subsubsection{Intimacy}

In relation to the case which discussed in previous paragraphs, the great jurists are not consent and the subject is on ambiguity. In fact, there are two problems: first, when the child is son, is he intimate with woman who grown on her womb? Second, when child is girl, is she intimate with her husband in relation to it, respond of Ayatolllah Sanei is significant. He says: the child belongs to owners of embryo and it shall be considered that husband of woman who had child in her womb, is not father, since he is not owner of sperm, so that it is prohibited to name woman as mother. Thus the child is not intimate to woman of owner sperm and he is like stepson and intimacy is used by matrimony. 9sanei, 20009, p. 61)

\subsubsection{Heritage}

Heritage of child is so important. Lacking recognition of duty is problematic. In this regard, as for theory of jurists, we cannot conclude final result. For example, Ayatollah Makarem Shirazi and Ayatollah Khamenei considered it. Ayatollah Mosavi Tabrizi voted for heir of child from owner of sperm. From Ayatollah Sanei point of view, in the case of presenting gamete, child heirs from husband of woman.

Heritage discussion is so vital and there is not annex in it but the verdict of exceptional cases is not publicized and shall be sufficient in exceptional cases. (Same, p. 263)

\subsection{Child Maintenance, Education, Alimony and Respect}

From important discussions which is cited about presenting and gifting embryo, is contents of article 23 of law for presenting embryo into infertile couples. In fact, this article points to 4 duties of couples which are described: 
1- Maintenance: in this article, maintenance is pointed and in order to know duties of parents, we shall refer to civil law. In article 1168 of civil law, parents maintain child and it is regarded as right. This right is named as right of maintenance. Also, in relation to priority of maintenance and other elements and duties of parents, it is follower articles 1169 and 1175. (Hazrati, 2008, p. 10)

2- Education of child: this task is like as article 3 of law for presenting embryo into infertile couples like duties inserted in article 1178 and said: the parents are entitled to cat based on their ability and don't neglect it. In addition, article 1173, 1179, 1188 and 1235 cited regulations about it.

3- Child Alimony: based on article 1199 of civil law, alimony of child is due to father. After father's death or lacking his ability to pay it, it is due to father ancestor and in absence them, it is due to mother. In the lacking alive of mother, or lacking her power to pay it, the alimony is due to mother ancestors. In this article, the policy maker regards father and mother for paying alimony. As for article 3 of law for presenting embryo, this duty is due to receivers of embryo (father and mother). (Fazel Lankarani, 2003, pp 203)

4- Respect: respect to child and following child from father and mother is ethical effective elements in survival of societies. Islam emphasizes upon respect of child and parents so much.

\subsubsection{Nationality}

Iran as a country where send migrants follows blood system about nationality and the children born from Iranian father are regarded as Iranian wherever they born. (Paragraph 2 of article 976 of civil law) but it is not mean soil rejects. As displayed in paragraph 1 of this article, all Iranian residents excluding persons have foreign nationality are Iranian. Based on it, the children born by presenting embryo if are in Iran, are Iranian (soil system), those relate child to owner of sperm shall regard him as Iranian (Same).

\subsubsection{Nationality and Volition Theory}

In this theory, as for protest of owner of sperm, blood system is not acted. Thus, in order to determine nationality of child, soil system is done or nationality of receivers is cited. Since nationality is a legal system which considers child expedient, it shall be cleared that which method is benefited for society. As for especial situation of child and slight number of it and lacking serious effects, it seems that society expedient scarified to personal expedient and nationality is publicized. (Sum of writers, 2005, pp 179)

\section{Conclusion}

Embryo transmission is one of important subjects which discussed in different countries like Iran from legal point of view and the laws were approved. Law for manner of embryo transmission solved problem of infertile couples somewhat. This law enables infertile wife and husband to accept embryo from other husband and woman to reach in their dream for having child. There are approaches for it which recognizes the duties. As law cited; duties and tasks of the couple's receivers are same as duties of parents. As for legal and ethical values of society, use of this method is limited to infertile couples and it is necessary to have legal matrimony between them.

As for above, it is displayed that in our law, instead of innovations and positive aspects, it has imperfects which pointed to them and the regulations are cited for presenting embryo into infertile couples. Whereas, there are other laws which are silent like present sperm or ovum, form embryo in in vitro with sperm of other couple and its transmission into womb of same woman, receive in vitro embryo by single or widow in order to nurture in her womb, conclude embryo by sperm of husband after his death and executive warrant and transfer unpredicted embryo are effects due to transmission embryo, so that it is not pointed to prevention of matrimony between couples and alimony ( like alimony of parents) and one side duty which the receivers are entitled to do it, it is not pointed to hidden or absence nature of honors.

About heritage, law like as jurists don't accept heritage, because based on traditional theory, child belongs to owner of sperm and ovum and heirs them whereas, maybe owner of the embryo is unknown and doesn't want child, but the couples wanted child and accepted him and woman nurtured him in her womb and some of jurists regarded her as relative mother. Thus, expedient of child and family and society is that child belongs to couples who receive and there is heritage. Of course, this problem needs ijtihad and new policy making and maybe recognition of system expedient can solve it, so in developed countries, this problem was solved by policy making and passing from traditional theory. 


\section{References}

Akhundi Mahdi, 2002, Mohammadali Sadighi Gilani and Naser Amirjannnati, Spermatozoid Evaluation in non-blocked Azo Sperms by Histopathology and Cytology, Fertile and Infertile Medical Magazine, No.1.

Aliabadi rouhani Mohamad, 2007, Legal Verdict for Sperm Zygosis and Stranger Sperm, Legal and Judicial Magazine, no.13.

Almomen Mohammad, 1415, Great Words in New Problems, Qom, Islami Press.

Amid Hassan, 1995, Amid Persian Dictionary, volume $4^{\text {th }}$, Tehran, Amir Kabir.

Anonymous, 2010, Reproduction from Jurist and Law Point of View, sum of articles, Tehran, Samt Press.

Fazel Lankarani, Mohamadjavad, 2003, Confer, Ebn-e-Sina Research Center, New Reprodcution Methods from legal point of view, second edition, Tehran.

Feizollahi Nejat, 2010, Present Embryo in Iran's law, Tehran Jungle Press.

Ghafari Marefat, 2003, Developed Methods in Treatment infertility, sum of new articles about reproduction from jurist and legal point of view, second edition, samt Press.

Hazratishahin degh Samad, 2008, Effects of Artificial Zygosis, Tehran, Payame Amouzesh Magazine.

HazratiShahindegh, 2003, Samad: legal and judiciary placement of Artificial Zygosis, specialty magazine, Payame Amouzesh.

Jafarzadeh Mirghasem 2000, Legal Status for applying New Reprodcution Methods in humans, Fertile and Infertile Medical Magazine, No.1.

Jequier AM (2000).Male Inferility Mals Infertility-A Guide for the Clinician, Oxford (uk), Blackwell Science.

John Lawrence Hill: What Does it meant to be a "PARENT"? New York University Law Review, Vol66.

Khoei Seyedaboulghasem Mousavi, 1421 Legal problems, Revival Institute for Imam Khoeni Works, volume 4.

Mirhashemi Sorur, 2004, Artificial Zygosis in Legal and Judicial Thoughts of proponents and opponents, Family Legal Magazine, no.36.

Moin Mohamad, 2008, Moin Persian Dictionary, one volume, Tehran, Farhang Nama Press, first edition.

Nayebzadeh Abbas, 2001, Legal Discussion of Artificial Zygosis Method, first edition, Majd Press.

Rezania moallem Mohamadreza, 2003, Legal Status of child on due to Embryo Transmission, new Reproduction methods from legal point of view, Tehran, Ebn-e-Sina Research Center.

Rouhani Mohammadsadegh, 2010, Confer Problems, Qom, Imam Sadegh School

Safaei Seyedhossein and Emami Asadollah, 2002, Summary of Family right, $5^{\text {th }}$ Edition, Tehran, Mizan Press.

Samadi Ahari, Mohammadhashem, 2003, Relative due to Artificial Zygosis in Iran's law and Islam, Tehran, Ganje Danesh Library, first edition.

Sanei Yousef, 2009, Medical Confer, 11't edition, Qom, Meysam Tamar press, summer.

Shahidi Mahdi, 2006, Situation of right of in vitro child, sum of legal articles, first edition, Tehran, Majd Press.

Sum of writers, 2005, Present Gammet and Embryo in Treatment Infertility, Tehran, Samt Press, and Volume 1. 